\title{
新技術・新製品
}

\section{コークス炉における燃焼管理の 計算機制御システム}

樋口正昭 ${ }^{*}$ ）小泉哲人 ${ }^{*}$ )

長谷部新次 ${ }_{3 \text { ) }}^{*}$

\section{1. 緒言}

コークスは，製鉄原料として，その品位は，大量生産 システムの高炉操業に大きな影響を及汸す。しかしなが らコークス炉に括ける燃焼管理は多年にわたる計測化 . 自動化が検討されたにもかかわらず，工業規模での開発 は遅れていた，当社では，コークス品位の安定と向上， 省力および省エネルギーを目的として，計算機によるコ 一クス炉の燃焼管理の自動化・システム化開発し，福 山第 5 コークス炬, 京浜, 扇島第 1 コークス炬飞执いて このシステム化を工業規模で採用し，良好な成果をあげ ているので，ここに，その概要と操業結果を紹介する。

\section{2. システムの概要}

（1）個々の窒の炉温調節

装入から窒出までの乾溜サイクルに括ける，目標温度 パターンを，目標の火落時間，置時間，および装入物の 諸条件から推定し，実測温度との偏差によって，各窯の 供給然料ガス流量の調節量，拈よびウェストバルブ圧力 の調節量をタイプアウトする。この調節指針に従って手 動で変更を実施する。つぎに案出毎に実績值をフィード バックし，毎回，前記目標温度をバイアス修正する。

\section{（2）炉団の炉温自動調節}

上記, 個々の窯の目標温度と実測温度について, 30 分

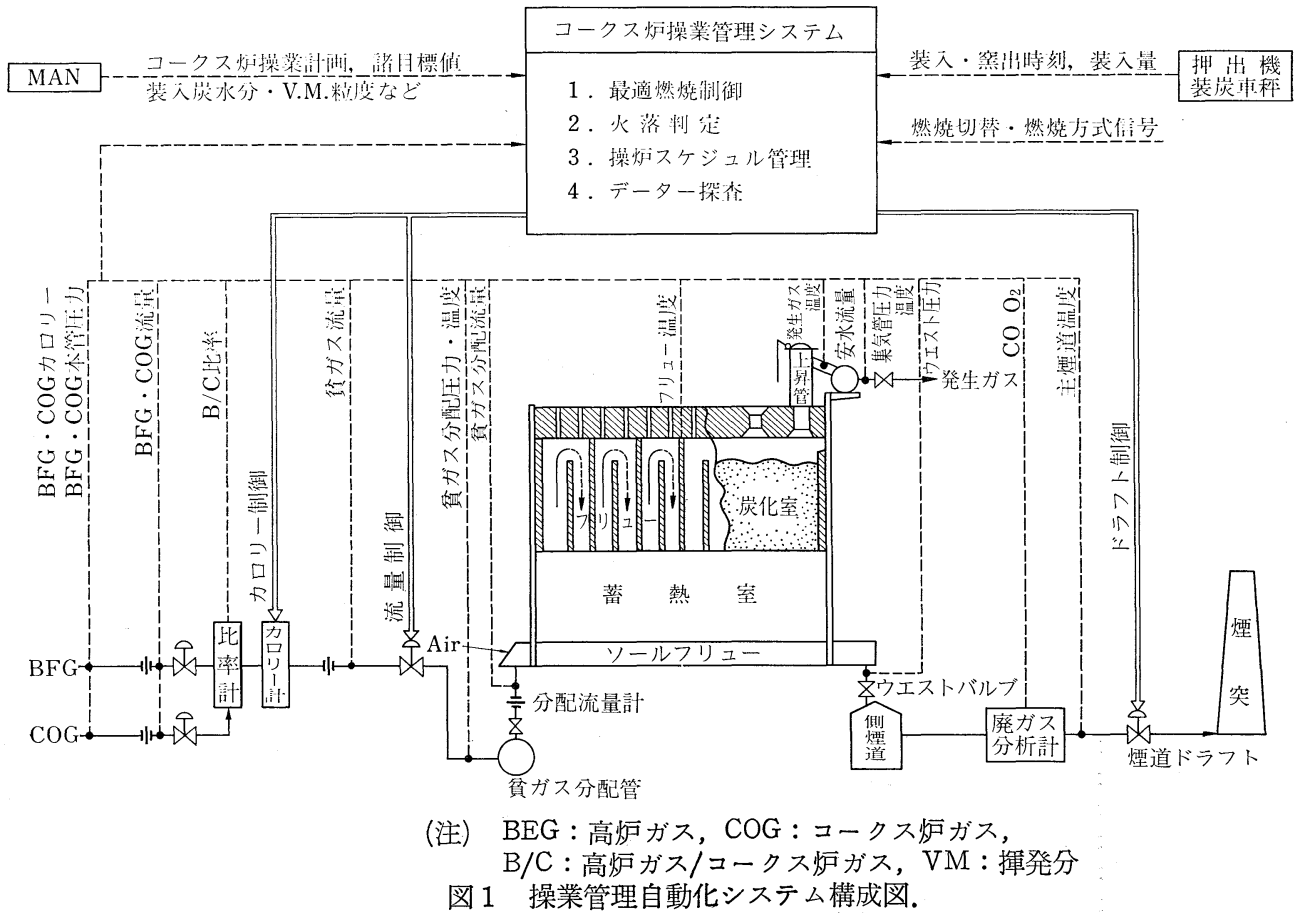

* 日本鋼管株式会社

1）鉄鋼技術部部長 2）環境管理部課長 3）福山製鉄所製鉄部 第2 コークスエ場コークス班長

Computer Control on Combusion System for Coke Battery; M.Higuchi, T.Koizumi, S.Hasebe (Nippon

Kokan K.K.)

1978 年 4 月 8 日受理
ごとに炻団平均值を算出する。 そして，その目標温度と 実測温度の偏差に応じて，供給燃料ガスの流量とカロリ 一を自動制御すると共に，燃料ガスの流量とカロリーの 変動に応じて最適燃焼が行われるように, 煙突ドラフト 
圧力を自動制御する.

以上，総合的なコンピューターによる，自動化システ ムの概要を図 1 に示した.

\section{（3）計測上の主な特徵}

(i) 炉温の検出法

当システムに打ける快温の検出は, フリューのへヤピ ントップに埋め込んだサーモカップルで行う。この温度 は, 燃料ガスの流路切替によって, 従来法のフリュ一底 部温度が約 $50^{\circ} \mathrm{C}$ 変化するのに対し, 変動がなく, 連続 的な測定が可能で，火落時間との相関性が，従来のフ リュ一底部温度に比較して高い(図 2,3)。

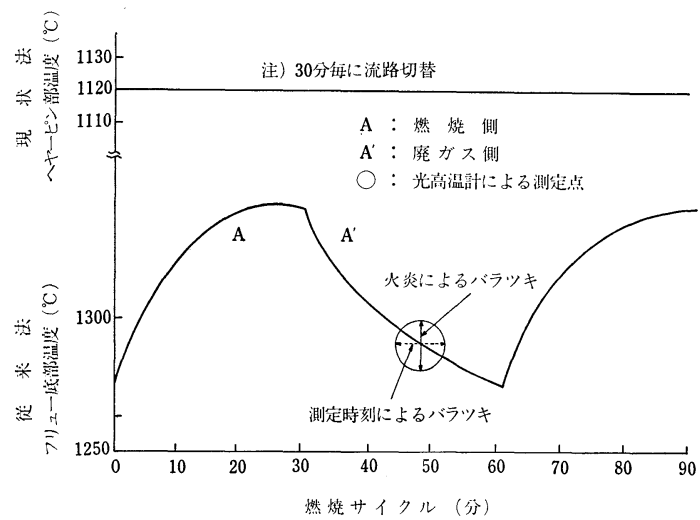

図 2 フリュ一温度の燃焼サイクルによる変動.

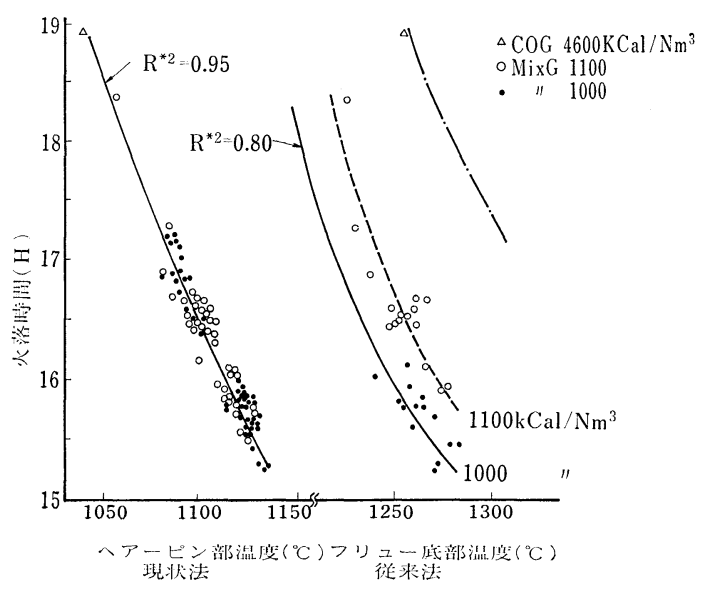

図 3 火落時間とフリ

(ii) 火落判定の自動化

従来の火落判定は, 炭化室から発生する未然ガスの 量，色による目視判定でなされてきたが，上昇管曲管部 に和汁る発生ガス温度によって計測化した。すなわち，
予め装入諸元よりの判定式 $(\mathrm{y} 0)$ と実測の発生ガス温度 曲線 $(\mathrm{yi})$ との交点 $(\mathrm{A})$ が火落点となる。このシステムに 上れば，目視判定のように昼夜間および判定者間の誤差 が入らないので，精度が高い(図4).

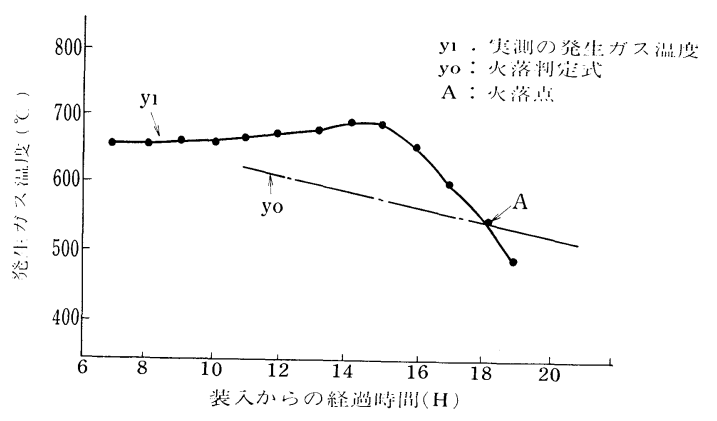

目 4 発生ガス温度による火落判定法.

\section{3. 開発の成果}

経験，勘にたよっていたコークス炉の燃焼管理につい て, 計算機を導入し, 自動制御を行った結果, つぎの効 果が確認された。

(i) 搳間の火落時間のバラッキ $\sigma_{\mathrm{w}}=33$ 分から 22 分 減少した。

(ii) コークス強度の向上特よびバラッキの減少

フリュ一温度のバラッキの減少により, $\mathrm{DI}_{15}^{30}$ が 0.25 向上した(強粘結炭 $3 \%$ 節約に相当).

(iii) コークス炉熱量原単位の低下

燃焼管理の向上により消費熱量が $10 \times 10^{3} \mathrm{kcal} / \mathrm{t}$ coal 減少した。

(iv) 省力化

フリ 一温度の連続測定, 火落判定の自動化, 個々の 案の燃焼管理の定量化により，5名省力化した。

(v) その他

火落判定の自動化の結果, 未然ガス放出がなくなり, 公害防止に寄与した。

\section{4. 特許}

すでに特許として，公開，登録されているるのは下記 のと打りである。

日本特許 公開番号 49-66183 (S 49.6.26)

日本特許 公開番号 49-103902 (S 49.10.2)

米国特許 No.4045292 (1977.8.30)

\section{5. その 他}

詳細については，日本鋼管技報，No.72(1976)を参照 下さい， 